\title{
PENGARUH KINERJA KEUANGAN TERHADAP HARGA SAHAM PADA PERUSAHAAN LQ45 YANG TERDAFTAR DI BURSA EFEK INDONESIA
}

\author{
Enjelina br Sembiring ${ }^{1}$, Ria Veronica Sinaga ${ }^{2}$ \\ ${ }^{1,2}$ Universitas Katolik Santo Thomas Jl. Setia Budi No.479 F, 20132, Indonesia \\ e-mail : riaveronicas@gmail.com
}

\begin{abstract}
This study aims to determine the effect of financial performance as measured by Current Ratio $(C R)$, Debt to Equity Ratio (DER), Total Asset Turnover (TATO), Return On Equity (ROE), and Earning Per Share (EPS) on stock prices at LQ45 companies listed on the Indonesia Stock Exchange. This research was conducted using secondary data with documentation techniques obtained through annual reports published on the Indonesia Stock Exchange, which can be viewed on the website www.idx.co.id. The population in this study was 45 companies listed on the Indonesia Stock Exchange in the 2015-2018 period. The sampling technique used was the purposive sampling method. The total sample of this study was 27 companies. The data analysis technique used is multiple regression analysis techniques by performing the classical assumption test, $t$-test, and $F$ test where the significance level is $5 \%$. The results of t-test research show that CR has a negative and significant effect on stock prices, DER has a positive and significant effect on stock prices, TATO has a positive and significant effect on stock prices, ROE has a negative and significant effect on stock prices, EPS has a positive and significant effect on stock prices. The results of the F test study indicate that $C R, D E R$, TATO, ROE, and EPS have a simultaneous and significant effect on stock prices.
\end{abstract}

Keywords: Current Ratio, Debt to Equity Ratio, Earning Per Share, and Stock Price.

\section{PENDAHULUAN}

Harga saham adalah salah satu ukuran yang digunakan oleh para investor untuk menilai mampu tidaknya dalam mengelola suatu perusahaan. Tinggi rendahnya harga saham mencerminkan baik tidaknya kondisi suatu perusahaan. Jika harga saham terus mengalami peningkatan maka para investor menilai bahwa perusahaan tersebut mampu/ berhasil dalam mengelola usaha yang dijalankan, dengan demikian maka akan membuat penilaian para investor terhadap perusahaan yang bersangkutan dinilai baik/bagus. Namun perlu diingat, para investor lebih menyukai saham perusahaan yang harganya tidak terlalu berfluktuasi tinggi, karena saham yang harganya berfluktuasi tinggi menimbulkan risiko yang tinggi pula bagi investor terutama bagi investor yang ingin berinvestasi dalam waktu jangka panjang.

Menjaga harga saham agar terus mengalami peningkatan adalah tanggung jawab pihak manajemen perusahaan, salah satu cara yang dapat dilakukan adalah dengan cara menjaga dan meningkatkan kinerja perusahaan yang tercermin dalam kinerja keuangan perusahaan. Dalam kaitannya dengan penelitian ini, penulis akan menganalisis salah satu faktor yang mempengaruhi harga saham, yaitu kondisi perusahaan. Kondisi perusahaan dalam hal ini diartikan sebagai kinerja keuangan perusahaan. Kinerja perusahaan merupakan suatu hal yang sangat penting, karena kinerja perusahaan berpengaruh dan dapat digunakan sebagai alat untuk mengetahui apakah perusahaan mengalami perkembangan atau sebaliknya. Ukuran kinerja perusahaan yang paling lama dan paling banyak digunakan adalah kinerja keuangan yang diukur dari laporan keuangan perusahaan. Analisis terhadap laporan keuangan dapat dilakukan dengan cara perhitungan rasio keuangan. Analisis rasio keuangan perusahaan akan memberikan gambaran atau penjelasan tentang baik atau buruknya kondisi keuangan perusahaan di masa lalu, sekarang, dan juga meramalnya di masa mendatang. Salah satu alat untuk menganalisis harga saham adalah dengan analisis ratio. Analisis ratio merupakan alat yang membantu kita untuk menganalisis laporan keuangan perusahaan sehingga kita dapat mengetahui kekuatan dan kelemahan suatu perusahaan. Analisis ratio juga menyediakan indikator yang dapat mengukur tingkat profitabilitas, likuiditas, pendapatan/ pemanfaatan asset dan kewajiban suatu perusahaan (Dharmastuti,2004:17). 


\section{Volume 20 Nomor 2, September 2020}

Dari berbagai macam jenis rasio yang digunakan untuk menilai kinerja keuangan, maka yang akan dibahas dalam penelitian ini adalah Current Ratio (CR), Debt To Equity Ratio (DER),Total Asset Turnover (TATO), Return On Equity (ROE), dan Earning Per Share (EPS).

Beberapa hasil penelitian yang mendukung penelitian ini adalah penelitian yang sebelumnya telah dilakukan oleh Puspitasari (2014:4) dengan judul Pengaruh Kinerja Akuntansi dan Kinerja Keuangan terhadap Harga Saham pada Perusahaan Sektor Keuangan yang Listing di Bursa Efek Indonesia, yang mendapatkan hasil penelitianya itu laba operasi dan EPS berpengaruh positif dan signifikan terhadap harga saham, ROA berpengaruh negatif dan signifikan terhadap harga saham, dan ROE berpengaruh negatif dan tidak berpengaruh signifikan terhadap harga saham. Kemudian hasil dari penelitian Putra dkk. (2013) dengan judul penelitian Pengaruh Kinerja Keuangan terhadap Harga Saham pada Perusahaan BUMN (Non-Bank) yang terdaftar di Bursa Efek Indonesia, menyatakan bahwa CR, ROI, ROE, dan TATO berpengaruh secara positif signifikan terhadap harga saham.

Dari penelitian-penelitian yang telah dilakukan dapat ditunjukkan hasil yang tidak konsisten untuk waktu dan tempat yang berbeda. Hal ini menarik perhatian penulis untuk melakukan penelitian lebih lanjut mengenai pengaruh kinerja keuangan terhadap harga saham.

Berdasarkan uraian latarbelakang di atas serta mengacu pada judul penelitian, maka rumusan masalah dalam penelitian ini adalah:

1. Apakah kinerja keuangan yang diukur dariCurrent Ratio, Debt to Equity Ratio, Total Asset Turnover, Return On Equity,dan Earning Per Share berpengaruh secara parsial dan signifikan terhadap harga saham pada perusahaan LQ45 yang terdaftar di Bursa Efek Indonesia?

2. Apakah kinerja keuangan yang diukur dari Current Ratio, Debt to Equity Ratio, Total Asset Turnover, Return On Equity, dan Earning Per Share berpengaruh secara simultan dan signifikan terhadap harga saham pada perusahaanLQ45 yang terdaftar di Bursa Efek Indonesia?

\section{Kinerja Keuangan}

\section{TINJAUAN PUSTAKA}

Kinerja keuangan sebagai refleksi gambaran dari pencapaian keberhasilan perusahaan dapat diartikan sebagai hasil yang telah dicapai atas berbagai aktivitas yang telah dilakukan. Kinerja keuangan yang dilihat berdasarkan laporan keuangan yang disajikan oleh manajemen akan member arti pada saat dianalisis terhadap pelaksanaankinerja yang telah dilakukan. Dari hasil analisis tersebut nantinya akan dapat diketahui tingkat kesehatan perusahaan dan juga dapat diketahui kelemahan maupun prestasi yang dimiliki perusahaan, sehingga pihak-pihak yang berkepentingan dapat menggunakannya sebagai bahan dalam pengambilan keputusan.

\section{Pengukuran Kinerja Keuangan}

Pengukuran kinerja keuangan perusahaan menurut Munawir (2014:31) adalah:

1. Mengetahui tingkat likuiditas. Likuiditas menunjukkan kemampuan suatu perusahaan untuk memenuhi kewajiban keuangan yang harus segera diselesaikan pada saat ditagih.

2. Mengetahui tingkat solvabilitas. Solvabilitas menunjukkan kemampuan perusahaan untuk memenuhi kewajiban keuangannya apabila perusahaan tersebut dilikuidasi, baik keuangan jangka pendek maupun jangka panjang.

3. Mengetahui tingkat rentabilitas.

Rentabilitas atau yang sering disebut dengan profotabilitas menunjukkan kemampuan perusahaan untukmenghasilkan laba selama periode tertentu.

4. Mengetahui tingkat stabilitas. Stabilitas menunjukkan kemampuan perusahaan untuk melakukan usahanya dengan stabil, yang diukur dengan mempertimbangkan kemampuan perusahaan untuk membayar hutang-hutangnya tepat pada waktunya.

\section{Rasio Keuangan}

Rasio keuangan merupakan kegiatan membandingkan angka-angka yang ada dalam laporan keuangan dengan cara membagi satu angka dengan angka lainnya (Kasmir 2010:93). Perbandingan dapat dilakukan antara satu komponen dengan komponen dalam satu laporaan keuangan atau antar komponen yang ada di antara laporan keuangan. 


\section{Volume 20 Nomor 2, September 2020}

Rasio-rasio yang dimaksud adalah sebagaiberikut:

1. Rasio Likuiditas. Rasio likuiditas merupakan suatu indikator mengenai kemampuan perusahaan membayar semua kewajiban fianansial jangka pendek pada saat jatuh tempo dengan menggunakan aktiva lancar yang tersedia (Syamsuddin 2004:41).

2. RasioSolvabilitas. Solvabilitas suatu perusahaan menunjukkan kemampuan perusahaan untuk memenuhi kewajiban finansialnya baik jangka pendek maupun jangka panjang apabila perusahaan dilikuidasi. Menurut Kasmir (2010:112) rasio solvabilitas merupakan rasio yang digunakan untuk mengukur sejauh mana aktiva perusahaan dibiayai dengan utang.

3. Rasio Aktivitas. Rasio aktivitas adalah rasio yang mengukur seberapa efektif perusahaan dalam memanfaatkan semua sumber daya yang ada padanya. Semua rasio aktivitas ini melibatkan perbandingan antara tingkat penjualan dan investasi pada berbagai jenis aktiva. Rasio-rasio aktivitas menganggap bahwa sebaiknya terdapat keseimbangan yang layak antara penjualan dan beragam unsur aktiva misalnya persediaan, aktiva tetap dan aktivalainnya.

4. Rasio Profitabilitas. Rasio ini mengukur kemampuan perusahaan menghasilkan keuntungan (profitabilitas) pada tingkat penjualan, aset, dan modal saham yang tertentu.

5. Rasio Nilai Pasar. Rasio pasar yaitu rasio yang mengukur harga pasar relatif terhadap nilai buku. Sudut pandang rasio ini lebihb anyak berdasar pada sudut investor atau calon investor, meskipun pihak manajemen juga berkepentingan terhadap rasio-rasio ini.

\section{HargaSaham}

Harga saham adalah nilai bukti penyertaan modal pada Perseroan Terbatas (PT) yang telah terdaftar di Bursa Efek, dimana saham tersebut telah beredar. Menurut Rusdi (2006:68) dalam (Halimatussakdiah, 2018:18) harga saham adalah harga suatu saham pada pasar yang sedang berlangsung, jika bursa sudah ditutup maka harga saham tersebut adalah harga penutupannya. Elemenelemen dari harga saham adalah sebagai berikut:

1. Open. Open adalah harga pembukaan atau harga perdagangan pertama untuk suatu periode (misalnya harga perdagangan pertama untuk hari ini).

2. High. High adalah harga tertingi atau harga perdagangan terting untuk suatu periode. High adalah titik dimana ada lebih banyak penjual dari pada pembeli (artinya selalu ada penjual yang bersedia menjual pada harga yang lebih tinggi). High juga mencerminkan harga tertinggi dimana pembeli bersedia membayar.

3. Low. Low adalah harga terendah atau harga perdagangan terendah untuk suatu periode. Low adalah titik dimana ada lebih banyak pembeli dari pada penjual (artinya selalu ada pembeli yang bersedia membeli dapat harga yang lebih rendah). Low juga mencerminkan harga terendah dimana penjual bersedia menerima.

4. Close. Close adalah harga penutup atau harga perdagangan terakhir untuk suatu periode.

5. Bid. Bid adalah harga dimana pembeli bersedia membayar untuk suatu saham.

6. Ask. Ask adalah harga dimana penjual bersedia menerima untuk suatu saham.

\section{Indeks LQ45}

Indeks LQ 45 adalah nilai kapitalisasi pasar dari 45 saham dengan likuiditas tinggi, yang diseleksi melalui beberapa kriteria pemilihan. Selain penilaian atas likuiditas, seleksi atas saham-saham tersebut mempertimbangkan kapitalisasi pasar (Sundjaja dan Berlian 2003:445).Indeks LQ 45 menggunakan 45 saham yang terpilih berdasarkan likuiditas perdagangan saham dan disesuaikan setiap enam bulan (setiap awal bulan Februari dan Agustus). Dengan demikian saham yang terdapat dalam indeks tersebut akan selalu berubah.

Beberapa kriteria-kriteria seleksi untuk menentukan suatu emiten dapat masuk dalam perhitungan Indeks LQ 45 adalah :

1. Kriteria yang pertamaadalah :

a. Berada di TOP $95 \%$ dari total rata-rata tahunannilaitransaksisaham di pasar reguler.

b. Berada di TOP $90 \%$ dari rata-rata tahunankapitalisasi pasar

2. Kriteria yang keduaadalah :

a. Merupakan urutan tertinggi yang mewakili sektornya dalam klasifikasi industri BEJ sesuai 
dengan nilai kapitalisasi pasarnya.

b. Merupakan urutan tertinggi berdasarkan frekuensi transaksi.

Indeks LQ 45 hanya terdiri dari 45 saham yang telah terpilih melalui berbagai kriteria pemilihan, sehingga akan terdiri dari saham-saham dengan likuiditas dan kapitalisasi pasar yang tinggi. Menurut Sundjaja dan Berlian (2003:445) saham-saham pada Indeks LQ 45 harus memenuhi kriteria dan melewati seleksi utama sebagai berikut :

1. Masuk dalam urutan 60 terbesar dari total transaksi saham di pasar reguler (rata-rata nilai transaksi selama 12 bulan terakhir).

2. Urutan berdasarkan kapitalisasi pasar (rata-rata kapitalisasi pasar selama 12 bulan terakhir)

3. Telah tercatat di BEJ minimum 3 bulan

4. Kondisi keuangan perusahaan dan prospek pertumbuhannya, frekuensi dan jumlah hari transaksi pasar reguler.

Saham-saham yang termasuk didalam LQ 45 terus dipantau dan setiap enam bulan akan diadakan review (awal Februari, dan Agustus). Apabila ada saham yang sudah tidak masuk criteria maka akan diganti dengan saham lain yang memenuhi syarat. Pemilihan saham-saham LQ 45 harus wajar, oleh karena itu BEJ mempunyai komite penasehat yang terdiri dari para ahli di BAPEPAM, Universitas, dan Profesional di bidang pasar modal.

\section{Pengaruh Current Ratio (CR) terhadap Harga Saham}

Rasio lancar menunjukkan sejauh mana aktiva lancar menutupi kewajiban-kewajiban lancar. Semakin besar perbandingan aktiva lancar dan kewajiban lancar semakin tinggi kemampuan perusahaan menutupi kewajiban jangka pendeknya.Tingginya nilai CRdapat meningkatkan minat investor untuk ikut berinvestasi dengan membeli saham dari perusahaan tersebut, maka hal ini menyebabkan harga sahamnya akan naik. Hal ini menunjukkan bahwa CRberpengaruh positif terhadap harga saham.

\section{Pengaruh Debt to Equity Ratio (DER) terhadap HargaSaham}

Debt to Equity Ratio (DER) adalahrasio yang membandingkan jumlah hutang terhadap ekuitas. Semakin besar DER menunjukkan bahwa struktur modal lebih banyak memanfaatkan hutang dibandingkan ekuitas. Jika suatu perusahaan memiliki jumlah hutang yang cukup besar maka kinerja mereka dikatakan kurang baik dan kurang mampu dalam menarik investor untuk berinvestasi di perusahaan tersebut. Sehingga dapat disimpulkan, suatu perusahaan yang memiliki jumlah hutang atau tingkat DER yang tinggi, berpotensi untuk menurunkan harga saham.

\section{Pengaruh Total Asset Turnover (TATO) terhadap HargaSaham.}

Total Assets Turnover(TATO) merupakan rasio yang menggambarkan perputaran aktivadiukur dari volume penjualan. Jadi semakin besar rasio ini semakin baik yang berarti aktiva dapat lebih cepat berputar dan meraih laba serta menunjukkan semakin efisien penggunaan keseluruhan aktiva dalam menghasilkan penjualan. Nilai TATO yang tinggi mengindikasikan efektivitas penggunaan aktiva dalam menghasilkan penjualan. Hasil akhirnya tentu adalah laba yang tinggi dan kinerja keuangan yang semakin baik serta dapat meningkatkan harga saham.

\section{Pengaruh Return On Equity (ROE) terhadap Harga Saham}

Return on Equity Ratio(ROE) adalah rasio profitabilitas yang mengukur kemampuan perusahaan untuk menghasilkan laba dari investasi pemegang saham di perusahaan tersebut. Dengan kata lain, ROE ini menunjukkan seberapa banyak keuntungan yang dapat dihasilkan oleh perusahaan dari setiap satu rupiah yang diinvestasikan oleh para pemegang saham. ROE yang meningkat, menunjukkan bahwa kinerja perusahaan meningkat serta perusahaan lebih efektif dan efisien menggunakan equity. Dengan demikian investor percaya bahwa perusahaan dapat memberikan pendapatan yang lebih besar melalui dividen yang akan dibagikan. Sehingga akhirnya akan dapat meningkatkan harga saham.

\section{Pengaruh Earning Per Share (EPS) terhadap Harga Saham}




\section{Volume 20 Nomor 2, September 2020}

Earning Per Share (EPS) merupakanrasio pasar yang digunakan untuk mengukur seberapa besar pengakuan pasar akan suatu perusahaan dengan membandingkan antara laba bersih dengan jumlah lembar saham yang beredar di pasaran. Semakin tinggi EPS suatu perusahaan, maka semakin tinggi pula pendapatan berupa deviden yang akan diterima investor dari investasinya, sehingga peningkatan EPS tersebut dapat member dampak positif terhadap harga sahamnya di pasar. EPS yang lebih besar dalam menghasilkan keuntungan bersih bagi pemegang saham, keadaan ini akan mendorong harga saham mengalami kenaikan.

\section{Populasi dan Sampel}

\section{METODE PENELITIAN}

Populasi dalam penelitian ini adalah perusahaan yang termasuk kategori perusahaan LQ45 sebanyak 45 perusahaan yang terdaftar di Bursa Efek Indonesia (BEI).Tehnik pengambilan sampel yang digunakan adalah Purposive Sampling, penentuan sampel dengan pertimbangan tertentu. Adapun kriteria yang digunakan dalam penelitian ini adalahsebagai berikut :

1. Perusahaan yang terdaftar di Bursa Efek Indonesia sebagai emiten kategori LQ45 selama periode penelitianya itu tahun 2015-2018.

2. Perusahaan yang terdaftar dalam perhitungan indeks LQ45 selama 4 tahun yaitu periode 20152018.

3. PerusahaanLQ45 yang mempublikasikan laporan keuangan tahunan secara lengkap dan telah di audit dari tahun 2015-2018.

Berdasarkan kriteria diatas, perusahaan yang memenuhi kriteria menjadi sampel adalah sebanyak 27 perusahaan.

\section{Operasionalisasi Variabel}

\section{Dependent Variable (Y)}

Variabel dependent dari penelitian ini adalah harga saham. Harga saham merupakan harga jual beli yang berlaku di Bursa Efek yang ditentukan oleh kekuatan pasar dalam arti tergantung pada kekuatan permintaan dan penawaran. Harga saham dilihat dari harga penutupan (closing price).

\section{Independent Variable $(\mathrm{X})$}

Variabel independent dalam penelitian ini adalah:

a. Current Ratio $\left(\mathrm{X}_{1}\right)$ adalah rasio untuk mengukur kemampuan perusahaan membayar kewajiban jangka pendek atau utang yang segera jatuh tempo pada saat ditagih secara keseluruhan yang diukur dengan perbandingan antara aktiva lancar dengan kewajiban lancar.

b. Debt to Equity Ratio $\left(\mathrm{X}_{2}\right)$ menggambarkan perbandingan antara total utang dengan total ekuitas perusahaan yang digunakan sebagai sumber pendanaan usaha.

c. Total Asset Turnover $\left(\mathrm{X}_{3}\right)$ adalah rasio yang berguna dalam melakukan pengukuran perputaran aktiva dan jumlah penjualan yang didapatkan perusahaan.

d. Return On Equity $\left(\mathrm{X}_{4}\right)$ adalah rasio profitabilitas yang mengukur kemampuan perusahaan untuk menghasilkan laba dari investasi pemegang saham di perusahaan tersebut.

e. Earning Per Share $\left(\mathrm{X}_{5}\right)$ menunjukkan berapa besar keuntungan (return) yang diperoleh investor atau pemegang saham per lembar saham.

\section{Teknik Analisis Data}

Teknik analisis data yang digunakan dalam penelitian ini adalah analisis regresi linier berganda yang dinyatakan dalam persamaan sebagai berikut :

$\mathrm{Y}=\alpha+\beta_{1} \mathrm{CR}+\beta_{2} \mathrm{DER}+\beta_{3} \mathrm{TATO}+\beta_{4} \mathrm{ROE}+\beta_{5} \mathrm{EPS}+\epsilon$

Keterangan:

$$
\begin{aligned}
& \mathrm{Y}=\text { Harga Saham } \\
& \alpha=\text { Konstanta } \\
& \beta_{1,} \beta_{2,}, \beta_{3}=\text { Nilai koefisien regresi variabel independent } \\
& \mathrm{CR} \quad=\text { Current } \text { Ratio } \\
& \mathrm{DER} \quad=\text { Debt to Asset } \text { Ratio }
\end{aligned}
$$




\section{Volume 20 Nomor 2, September 2020}

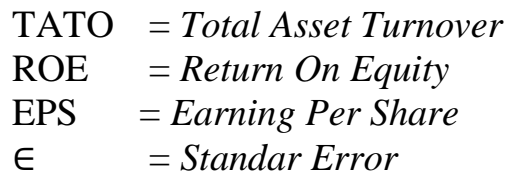

\section{PengujianAsumsi Klasik}

1. Uji Normalitas, digunakan untuk menguji apakah data variabeldependent dan independent pada persamaan regresibr distribusi normal atau tidak.

2. Uji Multi kolinearitas, bertujuan untuk menguji apakah model regresi ditemukan adanya korelasi antar variabel independent.

3. Uji Heterokedastisitas, bertujuan untuk menguji apakah dalam model regresi ini terjadi ketidaksamaan variance dari residual satu pengamatan kepengamatan yang lain. Model regresi yang baik tidak terjadi heterokedastisitas.

4. Uji Autokorelasi, dilakukan untuk menguji apakah model regresi ada korelasi antara kesalahan pengganggu pada periode $\mathrm{t}$ dengan kesalahan pada periode $\mathrm{t}-1$ (sebelumnya\} . Model regresi yang baik adalah regresi bebas dari auto korelasi.

\section{Uji Hipotesis}

Setelah dilakukan uji asumsi klasik maka tehnik analisis regresi dapat dilakukan dengan melakukan pengujian hipotesis. Pengujian hipotesis dilakukan dengan uji $\mathrm{F}$ untuk pengujian secara simultan dan uji t digunakan untuk pengujian secara parsial.

\section{HASIL PENELITIAN DAN PEMBAHASAN}

Uji Asumsi Klasik

Hasil Uji Normalitas, adalahse bagai berikut:
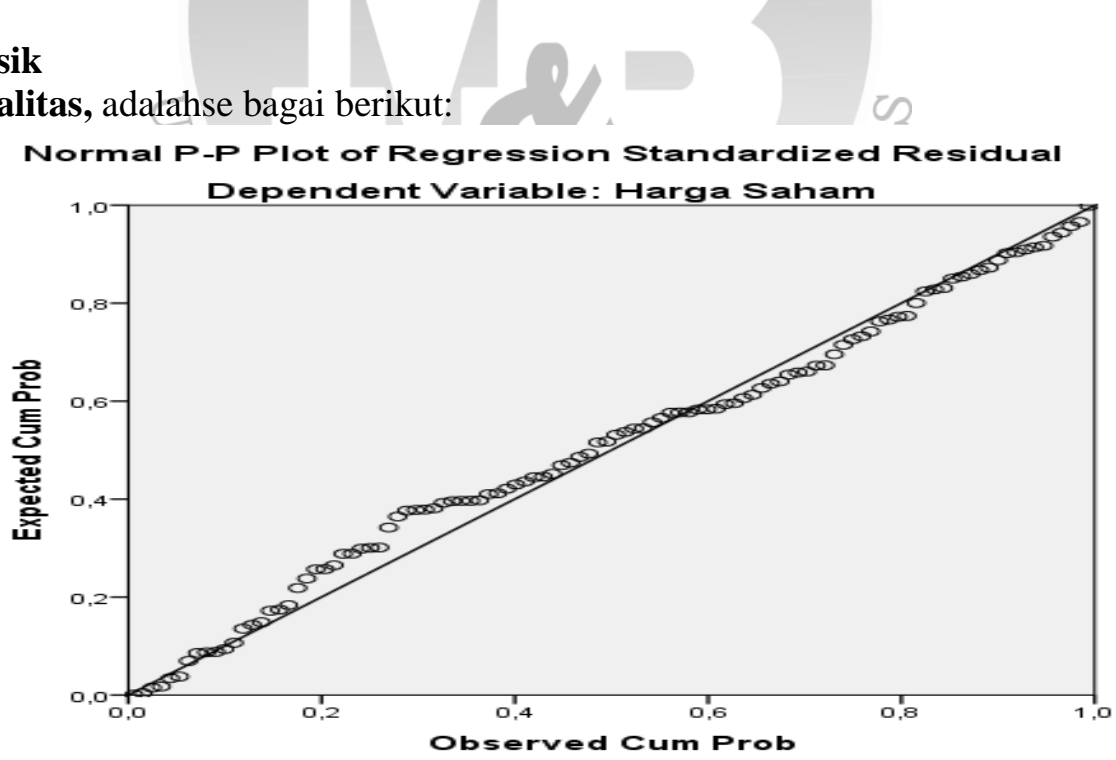

Gambar 1. Grafik Plot

Sumber: hasil pengolahan data SPSS v. 22

Dari gambar diatas, terlihat bahwa titik-titik variabel berada di sekitar garis Y-X atau menyebar disekitar garis diagram serta penyebarannya mengikuti arah garis diagonal, ini menunjukkan bahwa data telah terdistribusi normal.

Hasil Uji Multikolinearitas, adalah sebagai berikut:

Tabel 1. Coefficients ${ }^{\mathrm{a}}$

\begin{tabular}{|l|c|c|c|c|c|c|c|}
\hline \multirow{4}{*}{ Model } & \multicolumn{2}{|c|}{$\begin{array}{c}\text { Unstandardized } \\
\text { Coefficients }\end{array}$} & $\begin{array}{c}\text { Standardized } \\
\text { Coefficients }\end{array}$ & \multirow{2}{*}{} & \multicolumn{2}{|c|}{$\begin{array}{c}\text { Collinearity } \\
\text { Statistics }\end{array}$} \\
\cline { 2 - 4 } & $\mathrm{B}$ & Std. Error & Beta & $\mathrm{t}$ & Sig. & Tolerance & VIF \\
\hline
\end{tabular}


Volume 20 Nomor 2, September 2020

\begin{tabular}{|l|l|r|r|r|r|r|r|r|}
\hline 1 & (Constant) & 1,317 &, 351 & & 3,755 &, 000 & & \\
\cline { 2 - 9 } & CR &,- 058 &, 025 &,- 146 & $-2,267$ &, 026 &, 943 & 1,061 \\
\cline { 2 - 9 } & DER &, 208 &, 060 &, 244 & 3,463 &, 001 &, 790 & 1,266 \\
\cline { 2 - 9 } & TATO &, 311 &, 090 &, 246 & 3,439 &, 001 &, 771 & 1,297 \\
\cline { 2 - 9 } & ROE &,- 512 &, 094 &,- 435 & $-5,422$ &, 000 &, 611 & 1,635 \\
\cline { 2 - 9 } & EPS &, 732 &, 071 &, 817 & 10,297 &, 000 &, 626 & 1,598 \\
\hline
\end{tabular}

a. Dependent Variable: Harga Saham

Sumber: hasil pengolahan data SPSS v. 22

Berdasarkan tabel 2. diatas diperoleh hasil bahwa nilai tolerance dari masing-masing variabel independent $>0,1$ yang berarti tidak ada korelasi antara variabel bebas atau independen dan nilai VIF $<10$, sehingga dapat disimpulkan bahwa variabel independen dalam model regresi ini tidak terjadi multikolinearitas.

Hasil Uji Autokorelasi, adalah sebagai berikut:

Tabel 2.Model Summary ${ }^{\mathrm{b}}$

\begin{tabular}{|l|r|r|r|r|r|}
\hline Model & \multicolumn{1}{|c|}{ R } & R Square & Adjusted R Square & Std. Error of the Estimate & Durbin-Watson \\
\hline 1 &, $779^{\mathrm{a}}$ &, 606 &, 587 &, 33157 & 1,062 \\
\hline
\end{tabular}

a. Predictors: (Constant), EPS, DER, CR, TATO, ROE

b. Dependent Variable: Harga Saham

Sumber : hasil pengolahan data SPSS 22

Berdasarkan tabel 3. dapat dilihat hasil uji Durbin Watson sebesar 1,062, dengan nilai $\mathrm{DW}_{\text {hitung }}$ dalam rentang nilai -2 dan lebih kecil dari $+2(-2<1,062<+2)$. Oleh karena itu dapt disimpulkan bahwa tidak terjadi autokorelasi.

Hasil Uji Heterokedastisitas, adalah sebagai berikut:

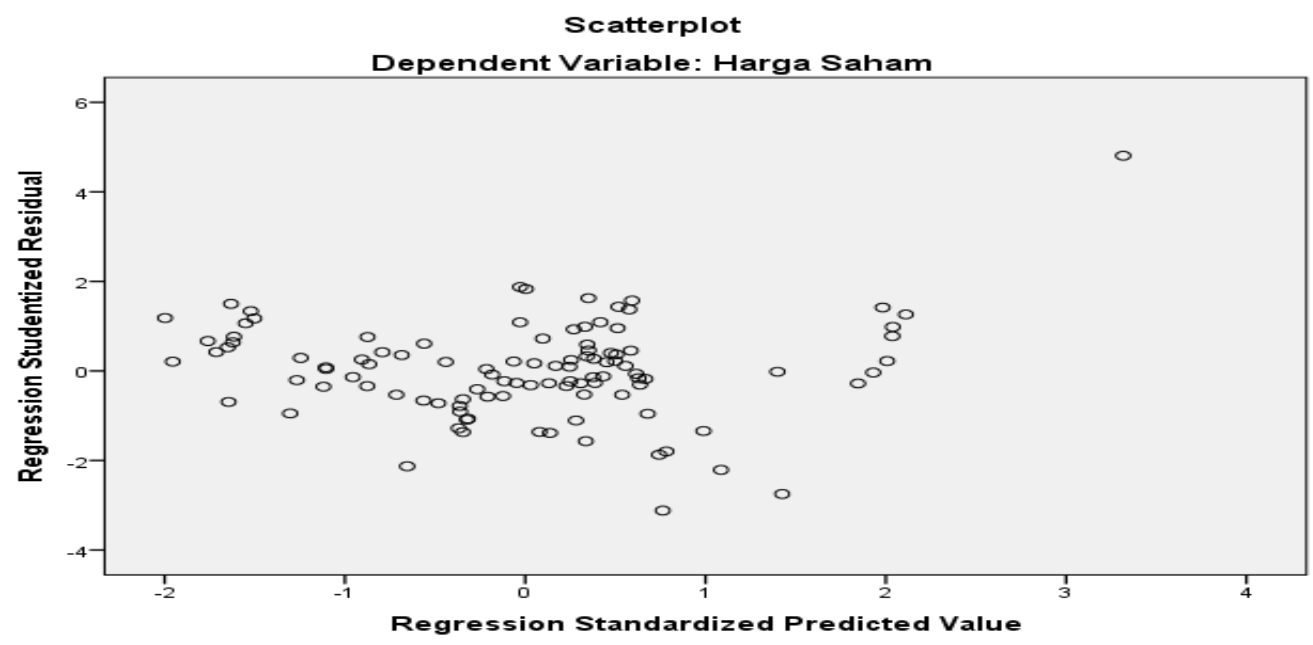

Gambar 2. Grafik Scatterplots

Sumber : hasil pengolahan data SPSS 22

Dengan melihat grafik scatterplot, terlihat titik-titik menyebar secara acak, serta tersebar baik diatas maupun dibawah angka 0 pada sumbu Y. Maka dapat diambil kesimpulan bahwa tidak terdapat gejala heterokedastisitas pada model regresi yang digunakan.

\section{Pengujian Hipotesis}

Dari hasil pengujian asumsiklasik dapat disimpulkan bahwa data telah terdistribusi dengan normal, tidak terdapat multi kolinearitas, auto korelasi, dan heterokedastisitas sehingga memenuhi persyaratan untuk melakukan pengujian atas hipotesis.

\section{Hasil Uji Pengaruh Simultan (Uji F)}


Volume 20 Nomor 2, September 2020

Tabel 3. ANOVA ${ }^{\mathrm{a}}$

\begin{tabular}{|l|l|r|r|r|r|c|}
\hline \multicolumn{2}{|l|}{ Model } & Sum of Squares & \multicolumn{1}{c|}{ Df } & Mean Square & F & \multicolumn{1}{c|}{ Sig. } \\
\hline \multirow{3}{*}{1} & Regression & 16,930 & 5 & 3,386 & 30,800 &, $000^{\mathrm{b}}$ \\
\cline { 2 - 7 } & Residual & 10,994 & 100 &, 110 & & \\
\cline { 2 - 7 } & Total & 27,924 & 105 & & & \\
\hline
\end{tabular}

a. Dependent Variable: Harga Saham

b. Predictors: (Constant), EPS, DER, CR, TATO, ROE

Sumber:Hasil pengolahan data SPSS v. 22

Dari tabel 4. diatas ditunjukkan bahwa Fhitung sebesar 30,800 dan $\mathrm{F}_{\text {tabel }}$ sebesar 2,30 (30,800

$>2,30$ ) dengan nilai signifikannya $0,000<0,05$. Dari hasil tersebut dapat disimpulkan bahwa current ratio, debt to equity ratio, total aset turnover, return on equity, dan earning per share berpengaruh secara simultan dan signifikan terhadap harga saham. Sedangkan uji parsial dari tabel 5 di atas menunjukkanbahwavariabel CR dan ROE berpengaruh negatif dan signifikan terhadap harga saham, sedangkanvariabel DER, TATO dan EPS berpengaruh positif dan signifikan terhadap harga saham.

\section{Nilai Koefisien Determinasi $\left(\mathbf{R}^{2}\right)$}

Tabel 4.Model Summary ${ }^{b}$

\begin{tabular}{|l|l|r|r|r|r|}
\hline Model & \multicolumn{1}{|c|}{$\mathrm{R}$} & R Square & Adjusted R Square & Std. Error of the Estimate & Durbin-Watson \\
\hline 1 &, $779^{\mathrm{a}}$ &, 606 &, 587 &, 33157 & 1,062 \\
\hline
\end{tabular}

a. Predictors: (Constant), EPS, DER, CR, TATO, ROE

b. Dependent Variable: Harga Saham

Sumber : hasil pengolahan data SPSS 22

Pada tabel 6. ditunjukkan bahwa koefisien determinasi R-square sebesar 0,606 atau 60,6\%. Hal ini menunjukkan bahwa sebesar $60,6 \%$ variasidarihargasahamdapatdijelaskandarikelima variabel independen CR, DER, TATO, ROE, dan EPS sedangkan sisanya sebesar 39,4\% dijelaskanoleh faktor lain diluar variabel penelitian.

\section{PEMBAHASAN}

Dari hasil analisis diperoleh persamaan regresi berganda $\mathbf{H S}=\mathbf{1 , 3 1 7}-\mathbf{0 , 0 5 8 C R}+\mathbf{0 , 2 0 8}$ DER + 0,311 TATO - 0,512 ROE + 0,732 EPS + e

Dari persamaan regresi linear berganda diatas dapat dijęlaskansebagaiberikut:

\section{Pengaruh CR terhadap Harga Saham}

Dari tabel 5. ditunjukkan bahwa variabel CR berpengaruh negatif dan signifikan terhadap harga saham. Besarnya pengaruh CR terhadap harga saham adalah sebesar - 0,058 yang artinya apabila CR naik sebesar $1 \%$ maka harga saham akan turun sebesar 0,058 . Selain itu dapat juga dilihat dari nilai $t$ hitung sebesar $-2,267$ dan $t$ tabel sebesar $1,98350(-2,267<1,98350)$ dengan nilai signifikansi $0,026<$ 0,05 , dengan demikian $\mathrm{H}_{\mathrm{o}}$ ditolak.

Semakin tinggi CR maka semakin besar kemampuan perusahaan dalam melunasi hutanghutangnya. Maka para kreditur dapat mempertimbangkan untuk memberikan pinjaman bagi perusahaan. Current ratio tidak memiliki pengaruh dikarenakan investor hanya melihat pada kegiatan usaha perusahaan tanpa melihat likuiditas perusahaan. Sehingga dari penelitian ini menunjukkan bahwa varibel CR tidak digunakan oleh investor sebagai pertimbangan dalam berinvestasi pada suatu perusahaan.

Untuk dapat memenuhi kewajiban jangka pendeknya yang akan segera jatuh tempo, perusahaan harus memiliki tingkat ketersediaan jumlah kas yang baik atau aset lancar lainnya yang dapat dengan segeradikonversi menjadi kas. Aktiva lancar dalam current ratio terdiri dari kas yang merupakan aktiva paling lancar dan diikuti dengan investasi jangka pendek (surat berharga), piutang usaha, wesel, persediaan bahan baku, perlengkapan dan aktiva lancar lain yang perlu dikonversi ke dalam kas untuk membayar kewajiban lancar yang segera jatuh tempo. Tidak berpengaruh positif kemungkinan diduga karena hubungan antara aktiva lancar dan kewajiban lancar tersebut menjadikan current ratio kurang diperhatikan oleh investor dalam mengukur kinerja perusahaan dalam memenuhi kewajiban jangka 


\section{Volume 20 Nomor 2, September 2020}

pendeknya. Hasil penelitian ini didukung oleh Deitiana (2011) dalam Pradana (2015:2) yang menyatakan bahwa likuiditas tidak berpengaruh positif terhadap harga saham, tetapi kontradiksi dengan Putra dkk (2013).

\section{Pengaruh DER terhadap Harga Saham}

Dari tabel 5. ditunjukkan bahwa variabel DER berpengaruh positif dan signifikan terhadap harga saham. Besarnya pengaruh DER terhadap harga saham adalah sebesar 0,208 yang artinya apabila DER naik sebesar $1 \%$ maka harga saham akan naik sebesar 0,208 . Selain itu dapat juga dilihat dari nilai t hitung sebesar 3,463 dan t tabel 1,98350 (3,463 > 1,98350) dengan nilai signifikansi $0,001<0,05$, dengan demikian $\mathrm{H}_{\mathrm{o}}$ ditolak.

Debt to Equity Ratio (DER) merupakan rasio kemampuan modal sendiri untuk membayar utang perusahaan. Keputusan untuk menambah hutang tidak hanya berdampak negatif, tetapi juga berdampak positif karena perusahaan berupaya menyeimbangkan manfaat yang ditimbulkan akibat hutang. Selama manfaat masih jauh lebih besar dari biaya hutang, maka hutang dapat ditambah. Akan tetapi jika terjadi sebaliknya maka hutang tidak boleh ditambah.

Semakin tinggi DER menunjukkan semakin besar total utang terhadap total ekuitasnya. Semakin tinggi DERjuga semakin tinggi penggunaan utang dalam pendanaan perusahaan dan ketergantungan perusahan dengan pihak luar. Namun jika utang dikelola dengan baik, maka hutang akan menjadi modal perusahaan tersebut di masa mendatang. Penilaian tersebut akan menarik minat investor dalam menanamkan modalnya yang berdampak pada naiknya harga saham perusahaan tersebut. Hasil penelitian ini didukung oleh Hildayanti (2019).

\section{Pengaruh TATO terhadap Harga Saham}

Dari tabel 5. ditunjukkan bahwaTATO berpengaruh positif dan signifikan terhadap harga saham. Besarnya pengaruh TATO terhadap harga saham adalah sebesar 0,311 yang artinya apabila TATO naik sebesar $1 \%$ maka harga saham akan naik sebesar 0,311 . Selain itu dapat juga dilihat dari nilai t hitung sebesar 3,439 dan t tabel sebesar 1,98350 (3,439>1,98350) dengan nilai signifikansi 0,001 $<0,05$, dengan demikian $\mathrm{H}_{\mathrm{o}}$ ditolak.

Total Asset Turnover (TATO) yaitu rasio yang digunakan untuk menggambarkan perputaran aktiva yang diukur dari total penjualan. Semakin besar rasio ini maka semakin baik, artinya aktiva lebih cepat berputar dalam mencapai laba dan menunjukkan semakin efisien penggunaan keseluruhan aktiva dalam menghasilkan penjualan.

Semakin tinggi tingkat efisiensi perusahaan dalam menggunakan aktiva penjualan maka akan menghasilkan laba yang semakin besar. Laba yang semakin tinggi akan berpengaruh positif pada minat investor untuk menanamkan saham di perusahaan tersebut. Dengan demikian menyebabkan permintaan akan saham semakin naik dan harga saham perusahaan semakin tinggi dalam pasar modal. Hasil penelitian ini didukung oleh Putra dkk. (2013), yang menyatakan bahwaTotal Asset Turnover (TATO) berpengaruh secara positif signifikan terhadap harga saham.

\section{Pengaruh ROE terhadap Harga Saham}

Return on equity (ROE) berpengaruh negatif dan signifikan terhadap harga saham. Besarnya pengaruh ROE terhadap harga saham adalah sebesar - 0,512 yang artinya apabila ROEturun $1 \%$ maka harga saham akan naik sebesar 0,512. Hal ini ditunjukkan dari nilai arah koefisien regresi. Selain itu dapat juga dilihat dari nilai thitung sebesar $-5,422$ dan $t$ tabel sebesar $1,98350(-5,422<1,98350)$ dengan nilai signifikansi $0,000<0,05$, dengan demikian $\mathrm{H}_{\mathrm{o}}$ ditolak.

Nilai ROE yang rendah belum tentu menjamin bahwa performa perusahaan tersebut buruk, karena bisa jadi kemungkinan perusahaan tersebut tidah memiliki hutang berlebih, tidak memiliki kerugian dari tahun-tahun sebelumnya, pendapatan sebelumnya juga relatif naik dan pembagian deviden juga relatif stabil. Karena persepsi setiap investor berbeda-beda, kemungkinan juga ROE bukan bahan acuan bagi para investor dalam meningkatkan harga saham sehingga para investor tetap tertarik menanamkan modalnya dalam perusahaan tersebut. Hasil penelitian ini didukung oleh Rahmadewi dan Nyoman (2018). 


\section{Volume 20 Nomor 2, September 2020}

\section{Pengaruh EPS terhadap Harga Saham}

Variabel EPS berpengaruh positif dan signifikan terhadap harga saham. Besarnya pengaruh EPS terhadap harga saham adalah sebesar 0,732 yang artinya apabila EPS naik sebesar 1\% maka harga saham akan naik sebesar 0,732. Selain itu dapat juga dilihat dari nilai t hitung sebesar 10,297 dan t tabel sebesar 1,98350 (10,297 > 1,98350) dengan nilai signifikansi $0,000<0,05$, dengan demikian $\mathrm{H}_{\mathrm{o}}$ ditolak.

Menurut Fahmi (2012:96) EPS adalah bentuk pemberian keuntungan yang diberikan kepada para pemegang saham dari setiap lembar saham yang dimiliki. EPS dihitung dengan cara membagikan laba bersih setelah pajak dengan jumlah saham biasa yang beredar. EPS merupakan salah satufaktor yang mempengaruhi harga saham. Adanya hubungan signifikan antara variabel EPS terhadap harga saham mengandung arti bahwa semakin besar EPS maka semakin baik kinerja keuangan perusahaan yang diukur dengan harga saham. Semakin tinggi EPS maka harga saham mengalami peningkatan sehingga tingkat keuntungan bagi pemegang saham semakin tinggi. Peningkatan harga saham perusahaan akan memberikan keuntungan yang tinggi pula bagi investor, sehinggga dalam hal ini EPS akan mempengaruhi kepercayaan investor pada perusahaan.

Dalam penelitian ini EPS didasarkan pada jumlah pendapatan yang diperoleh dalam satu periode untuk setiap lembar saham yang beredar. Yang mâna jumlah peningkatan EPS akan membuat pasar bereaksi positif dan akan mempengaruhi kepercayaan investor pada perusahaan, yang aktinya jikaEPS meningkat maka harga saham meningkat. Sehingga tingkat keuntungan bagi pemegang saham semakin tinggi. Hasil penelitian ini didukung oleh Hatta dan Dwiyanto (2012) dalam Puspitasari (2014:4).

\section{Kesimpulan}

\section{KESIMPULAN DAN SARAN}

Berdasarkan hasil penelitian dan pembahasan pada bab IV, maka kesimpulan dari penelitian ini adalah sebagai berikut :

1. Current Ratio dan Return On Equity berpengaruh negatif dan signifikanterhadap harga saham pada perusahaan LQ45 yang terdaftar di Bursa Efek Indonesia pada tahun 2015-2018. sehingga $\mathrm{H}_{\circ}$ ditolak

2. Debt to Equity Ratio, Total Asset Turnover dan Earning Per Share berpengaruh positif dan signifikan terhadap harga saham pada perusahaan LQ45 yang terdaftar di Bursa Efek Indonesia pada tahun 2015-2018, sehingga $\mathrm{H}_{0}$ ditolak

3. Hasil penelitian menunjukkan bahwa Current Assets (CR), Debt to Equity Ratio (DER), Return On Equity (ROE), Total Assets Turnover (TATO), dan Earning Per Share (EPS) secara simultan berpengaruh signifikan terhadap harga saham pada perusahaan LQ45 yang terdaftar di Bursa Efek Indonesia (BEI) periode 2015-2018.

\section{Saran}

Berdasarkan kesimpulan diatas maka penelitian ini disarankan beberapa hal sebagai berikut :

1. Bagi perusahaan, penelitian ini diharapkan dapat menjadi pertimbangan dalam membuat keputusan terhadap kebijakan keuangan agar dapat memaksimumkan nilai perusahaan. Kinerja keuangan yang baik akan memberikan signal yang positif terhadap para investor dalam melakukan investasi.

2. Bagi investor, diharapkan dapat lebih cermat dalam melihat faktor-faktor yang dapat mempengaruhi harga saham seperti kinerja keuangan dan faktor lain yang dapat mempengaruhi harga saham.

3. Bagi peneliti lain, penelitian ini diharapkan dapat menjadi masukan atau bahan pembanding bagi peneliti lain yang melakukan penelitian sejenis dalam bidang serupa, maupun untuk dikembangkan dengan melakukan penelitian selanjutnya. Selain itu peneliti dapat melakukan penelitian secara meluas dengan melakukan observasi terhadap saham pada sektor tertentu dan menambah kinerja keuangan atau faktor lainnya.

\section{DAFTAR PUSTAKA}

Adi, F Maulana. 2016. Analisis Pengukuran Kinerja Perusahaan Dengan Pendekatan Balance Scorecard Pada Perusahaan Penerbit Buku Deepublish CV. Budi Utama Yogyakarta. 
Ayuwardani, R. Primadita. 2018. Pengaruh Informasi Keuangan Dan Non Keuangan Terhadap Underpricing Harga Saham Pada perusahan Yang Melakukan Initial Public Offering (Studi Empiris Perusahaan Go Public Yang Terdaftar di Bursa Efek Indonesia Tahun 2011-2015). Jurnal Nominal, Vol. VII, No. 1, 2018.

Brigham, Eugene F. dan Joel F. Houston. 2011. Dasar-dasarManajemenkeuangan. Jakarta :Erlangga. Danu Pradana, A. Nugroho. 2015. Pengaruh Kinerja Keuangan Terhadap Harga Saham Pada Sektor LQ45 Di Bursa Efek Indonesia Periode 2009-2013.

Halimatussakdiah. 2018. Pengaruh Probabilitas, Likuiditas, Dan Deviden Per Share Terhadap Harga Saham Pada Perusahaan LQ45 Yang Terdaftar Di Bursa Efek Indonesia.

Hani, Syafrida, 2014. Teknik Analisa LaporanKeuangan. Medan: IN MEDIA.

Hildayanti, Reza. 2019. Pengaruh Return On Equity dan Debt To Equity Ratio Terhadap Harga Saham (Survey Pada Perusahaan Sub Sektor Otomotif dan Komponen yang Terdaftar Bursa Efek Indonesia periode 2015-2017.

Kasmir,. 2010. Pengantar Manajemen Keuangan. Edisi Pertama, Cetakan ke-2. Jakarta: Kencana

Munawir, S. 2014.Analisis Laporan Keuangan, Liberty, Yogyakarta.

M. Sadeli,lili. 2006. Dasar-dasarAkuntansi,PT.Bumi Aksara, Jakarta.

Putra, A. Cahya,Saryadidan W. Hidayat. 2013. Pengaruh Kinerja Keuangan Terhadap Harga Saham Pada Perusahaan Bumn (Non-Bank) Yang Terdaftar Di Bursa Efek Indonesia.Journal of Social And Politic Tahun 2013.

Puspitasari, C. Santi. 2014. Pengaruh Kinerja Keuangan Terhadap Harga Saham Perusahaan Yang Tergolong Ke Dalam Indeks LQ45 Yang Terdaftar Di Bursa Efek Indonesia. Jurnal Fakultas Ekonomi Universitas widyatama tahun 2014.

Rahmadewi, P. Widya dan Nyoman Abundanti. 2018. Pengaruh EPS,PER,CR, dan ROE terhadap harga saham di Bursa Efek Indonesia. E- Jurnal Manajemen Unud, Vol. 7, No. 4: 2106-2133

Rani, K. Stia,dan Ni Nyoman Ayu Diantini. 2015. Pengaruh Kinerja Keuangan Perusahaan Terhadap Harga Saham Dalam Indeks LQ45 Di BEI. E-Jurnal Manajemen Unud, Vol. 4, No. 6, 2015 : 1504-1524

Riswan dan Yolanda F. Kesuma. 2014. Analisis Laporan Keuangan Sebagai Dasar Dalam Penilaian Kinerja Keuangan PT. Budi Satria Wahana Motor. Jurnal Akuntansi dan keuangan Universitas Bandar Lampung, Vol. 5, No. 1, Maret 2014, Hal : 93-121.

Sawir, Agnes, 2003. AnalisaKinerjaKeuangandanPerencanaanKeuanganPerusahaan, PT. Gramedia Pustaka Utama, Jakarta.

Sriwahyuni, Endah Dan Rishi Septa Saputra. 2017. Pengaruh CR, DER, ROE, TAT, dan EPS Terhadap Harga Saham Industri Farmasi Di BEI Tahun 2011-2015. Jurnal Online Insan Akuntan, Vol 2, No. 1, Juni 2017, 119-136.

Sugiyono. 2015. Metode Penelitian Pendidikan (Pendekatan Kuantitatif, Kualitatif, dan R\&D). Bandung: ALFABETA

Sundjaja, Ridwan S dan Berlian, Inge. 2003. Manajemen Keuangan. Klaten: PT Intan Sejati.

Syamsuddin, Lukman. 1994. Manajemen Keuangan Perusahaan. Jakarta: PT Raja Grafindo Persada. 